\title{
KELAYAKAN FINANSIAL NEAR ZERO ENERGY BUILDING DENGAN PERATURAN KEMENTERIAN ENERGI DAN SUMBER DAYA MINERAL NO. 49 TAHUN 2018 MENGENAI INSENTIF ENERGI TERBARUKAN
}

\author{
(Near Zero Energy Building Financial Feasibility Under Ministry Of Energy And Mineral Resource \\ Regulation No. 49 Year 2018 On Renewable Energy Incentive)
}

\author{
Ario Bintang Koesalamwardi ${ }^{1}$, Andre Eldrian ${ }^{1}$, Irene $^{1}$, Wellie Tjahyadi ${ }^{1}$ \\ ${ }^{1}$ Program Studi Manajemen dan Rekayasa Konstruksi Universitas Agung Podomoro \\ E-mail: ario.bintang@podomorouniversity.ac.id
}

Diterima 15 April 2020, Disetujui 21 April 2020

\begin{abstract}
ABSTRAK
Industri konstruksi dan bangunan bertanggung jawab atas lebih dari 35\% konsumsi energi di dunia dan menghasilkan hampir 40\% emisi gas rumah kaca seperti $\mathrm{CO}_{2}$. Emisi $\mathrm{CO}_{2}$ berasal dari konsumsi energi bangunan dimana lebih dari $65 \%$ yang masih bersumber dari bahan bakar fosil. Near Zero-Energy Building (nZEB) adalah sistem bangunan yang memiliki efisiensi energi tinggi dan dapat menghasilkan listrik secara mandiri dari sumber energi terbarukan, sehingga mengurangi biaya operasional dari tagihan listrik tahunan secara signifikan di dalam umur pakainya. Pembangunan berkonsep ini akan menambah biaya konstruksi awal untuk penerapan desain hemat energi dan sistem pembangkit energi terbarukan pada bangunan. Kelayakan finansial bangunan dengan desain seperti ini diukur dengan metode analisis Life Cycle Cost yang juga memperhitungkan biaya operasional sepanjang umur pakainya. Insentif energi terbarukan merupakan faktor penting dalam analisis kelayakan finansial karena insentif ini secara langsung mengurangi biaya operasional (biaya listrik tahunan) bangunan. Kementerian Energi dan Sumber Daya Mineral (ESDM) telah menerbitkan peraturan baru mengenai besaran insentif yang diberikan kepada pemilik bangunan yang memasang pembangkit listrik dari sumber terbarukan. Perlu ada kajian mengenai dampak finansial dari diterbitkannya peraturan baru ini terhadap nilai finansial nZEB sebagai sebuah sistem bangunan utuh yang terintegrasi dengan pembangkit energi dari sumber terbarukan, terutama bangunan pemukiman padat. Tujuan dari penelitian ini adalah membandingkan kelayakan finansial nZEB yang menggunakan peraturan tahun 2013, dengan Peraturan Kementerian ESDM no. 49 tahun 2018, pada bangunan pemukiman padat berkonsep desain $n Z E B$. Penelitian ini menemukan nilai kelayakan finansial konsep desain nZEB di bawah peraturan insentif tahun 2013 lebih besar daripada di bawah peraturan tahun 2018.
\end{abstract}

Kata Kunci: Near Zero Energy Building, Analisis Life Cycle Cost, insentif energi terbarukan

\section{ABSTRACT}

The construction industry and building are responsible for more than 35\% of the world's energy consumption and produces almost $40 \%$ of greenhouse gas emissions such as $\mathrm{CO}_{2}$. The $\mathrm{CO}_{2}$ emissions come from building energy consumption where more than $65 \%$ of them is still generated from fossil fuels. Net Zero-Energy Building (NZEB) is a building system that has high energy efficiency and can generate electricity on-site from renewable energy sources, thereby reducing the operational costs of the annual electricity bill significantly in its whole life cycle. This design concept will add initial construction costs for the application of energy-efficient designs and renewable energy generation systems in buildings. The financial feasibility of a building with this design is measured by a Life Cycle Cost analysis method that also takes into account operational costs over its whole life cycle. Renewable energy incentives are an important factor in financial feasibility analysis because these incentives directly reduce the operational costs (annual electricity costs) of buildings. The Ministry of Energy and Mineral Resources (ESDM) has issued new regulations regarding the amount of incentives given to building owners who install renewable energy generators i.e. Photovolvtaic (PV) panels. There needs to be a study of the financial impact of the issuance of this new regulation on the financial value of NZEB as a whole building system that is integrated with energy generation from PV Panels, especially residential buildings. The purpose of this study is to compare the financial feasibility of NZEB using 2013 regulations, with Ministry of Energy and Mineral Resources Regulation no. 49 of 2018, in dense residential buildings with NZEB design concept. This research concludes the $n Z E B$ design is more financialy feasible under the 2013 renewable energy incentive regulation than the 2018 regulation.

Keywords: Near Zero Energy Building, Life Cycle Cost Analysis, renewable energy incentive 


\section{PENDAHULUAN}

Tingkat pertumbuhan populasi penduduk kawasan perkotaan di Indonesia adalah yang tercepat di kawasan Asia dengan nilai pertumbuhan $4,1 \%$ per tahun. Pada tahun 2025, 68\% dari penduduk Indonesia akan menghuni wilayah perkotaan. Sejak tahun 2010, kepadatan penduduk perkotaan di Indonesia melonjak dari 7.400 penduduk $/ \mathrm{km}^{2}$ menjadi 9.400 penduduk $/ \mathrm{km}^{2}$, sedangkan pertumbuhan lahan per penduduk hanya mencapai 40m ${ }^{2}$ (World Bank, 2016). Hal ini menyebabkan meningkatnya kebutuhan akan bangunan hunian padat seperti rumah susun (Bank Indonesia, 2018). Peningkatan kebutuhan bangunan hunian padat berpotensi menimbulkan permasalahan lingkungan. Badan Lingkungan Hidup dan Energi Internasional PBB padan tahun 2017 melaporkan industri konstruksi dan bangunan bertanggung jawab atas lebih dari 35\% konsumsi energi di dunia dan menghasilkan hampir $40 \%$ emisi gas rumah kaca seperti $\mathrm{CO}_{2}$. Emisi $\mathrm{CO}_{2}$ berasal dari konsumsi energi bangunan dimana lebih dari $65 \%$ yang masih bersumber dari bahan bakar fosil. Pada laporan yang sama, kunci dari pengurangan emisi gas rumah kaca seperti $\mathrm{CO}_{2}$ dari sektor ini adalah dengan mempercepat pengembangan teknologi dan konsep desain bangunan yang memiliki efisiensi energi tinggi dan beralih kepada penggunaan sumber energi baru dan terbarukan (EBT) untuk mencapai net-zero emission (emisi nol) pada sektor bangunan sebelum tahun 2060. Hal ini akan membutuhkan mekanisme pendanaan yang layak untuk memastikan pengembangan dan penerapan teknologi bangunan berkelanjutan dapat diimplementasikan secara menyeluruh (International Energy Agency and United Nations Environment Programme, 2017).

Konsep desain near Zero-Energy Building (nZEB) adalah konsep desain bangunan yang sangat hemat energi hingga angka konsumsi energi listriknya mendekati nol. Pencapaian ini diperoleh dengan menggunakan material dan desain selimut bangunan penghemat energi, dan kemudian mengaplikasikan sistem pembangkit energi listrik dari sumber yang bersih, berkelanjutan, baru dan terbarukan (EBT) seperti panel surya atau panel photovolataic (PV) (Abdellah, Masrom, Chen, Mohammed, \& Omar, 2017). Indonesia adalah negara yang terletak di garis khatulistiwa yang disinari oleh matahari sepanjang tahun. Hal ini menjadi potensi sekaligus tantangan dalam pengembangan konsep desain nZEB di Indonesia. Konsep desain nZEB yang memakai panel PV pada atapnya memiliki potensi untuk menghasilkan energi listrik dalam jumlah besar sepanjang tahun, sedangkan tantangannya adalah meminimalisir pemakaian pendingin udara. Sehingga desain nZEB pada daerah tropis akan memprioritaskan desain pasif untuk meminimalisir penetrasi radiasi panas dari luar dan sistem pembangkit listrik tenaga surya. Desain nZEB di daerah tropis dapat dicapai dengan beberapa langkah, yaitu: (1) mengarahkan fasad bangunan yang memiliki bukaan seperti pintu dan jendela tidak langsung ke arah terbit dan tenggelam matahari; (2) menggunakan material insulasi pada elemen selimut bangunan seperti atap, dan dinding luar untuk memperlambat laju penetrasi panas dari luar; (3) memperbesar rasio luas bukaan jendela dengan dinding fasad (window-to-wall ratio) untuk memaksimalkan pencahayaan alami; (4) akan tetapi, agar penetrasi panas tidak memasuki bukaan jendela yang diperluas secara berlebihan, pemasangan kanopi pada jendela juga perlu diterapkan; (5) pemakaian lapisan film pada kaca jendela juga perlu untuk meminimalisir penetrai panas berlebihan dari jendela; (6) menggunakan lampu hemat energi seperti lampu LED, dan peralatan rumah tangga hemat energi, dan; (7) mengarahkan panel PV menghadap arah matahari untuk memaksimalkan serapan cahaya matahari (Latief, Berawi, Koesalamwardi, Riantini, \& Petroceany, 2017). Dengan adanya sistem pembangkit listrik EBT seperti panel PV, nZEB membutuhkan interaksi dengan jaringan infrastruktur energi listrik (grid) agar listrik yang dihasilkan oleh nZEB dapat langsung diekspor ke jaringan listrik pusat. Interkoneksi dengan jaringan listrik pusat akan mengeliminasi kebutuhan baterai penyimpanan listrik yang mahal dan memerlukan perawatan tambahan. Listrik yang diekspor dapat mengurangi tagihan listrik pemilik bangunan yang memasang sistem pembangkit listrik EBT seperti panel PV (Dávi, Caamaño-Martín, Rüther, \& Solano, 2016; Latief, et al., 2017). Harga beli tersebut yang menjadi unsur dalam skema insentif bagi pemilik bangunan yang memasang panel PV pada bangunannya. Salah satu bentuk skema insentif EBT adalah net-metering.

Tingginya biaya awal konstruksi akibat dari peningkatan desain bangunan, menjadi kendala untuk pengembangan desain bangunan berkelanjutan seperti nZEB dan Green Building (Sarkar, Kumar, \& Sadhu, 2019; Berawi, Basten, Latief, \& Crévits, 2020). Desain konsep bangunan berkelanjutan seperti nZEB mendapatkan manfaat finansial berupa penghematan biaya listrik tahunan selama masa operasiionalnya. Besarnya insentif diatur oleh pemerintah, Indonesia melalui Perusahaan Listrik Negara (PLN) pada tahun 2013 melalui surat edaran Direksi Peraturan Direksi PLN no. 0733.K/DIR/2013 menerbitkan skema insentif EBT, net metering, yang menyatakan PLN membeli listrik yang dihasilkan oleh panel PV milik konsuen dengan harga sama dengan harga retail konsumen. Pada tahun 2018, Kementerian ESDM mengeluarkan peraturan insentif net-metering baru dengan Peraturan Menteri ESDM No. 49 tahun 2018 yang mengatur besaran harga beli PLN kepada konsumen pemilik panel PV, yaitu sebesar $65 \%$ dari harga retail. Dengan adanya peraturan baru ini, maka besarnya pengurangan biaya tagihan listrik juga akan mengalami perubahan, sehingga mempengaruhi nilai kelayakan finansial konsep desain nZEB yang menggunakan panel PV. 


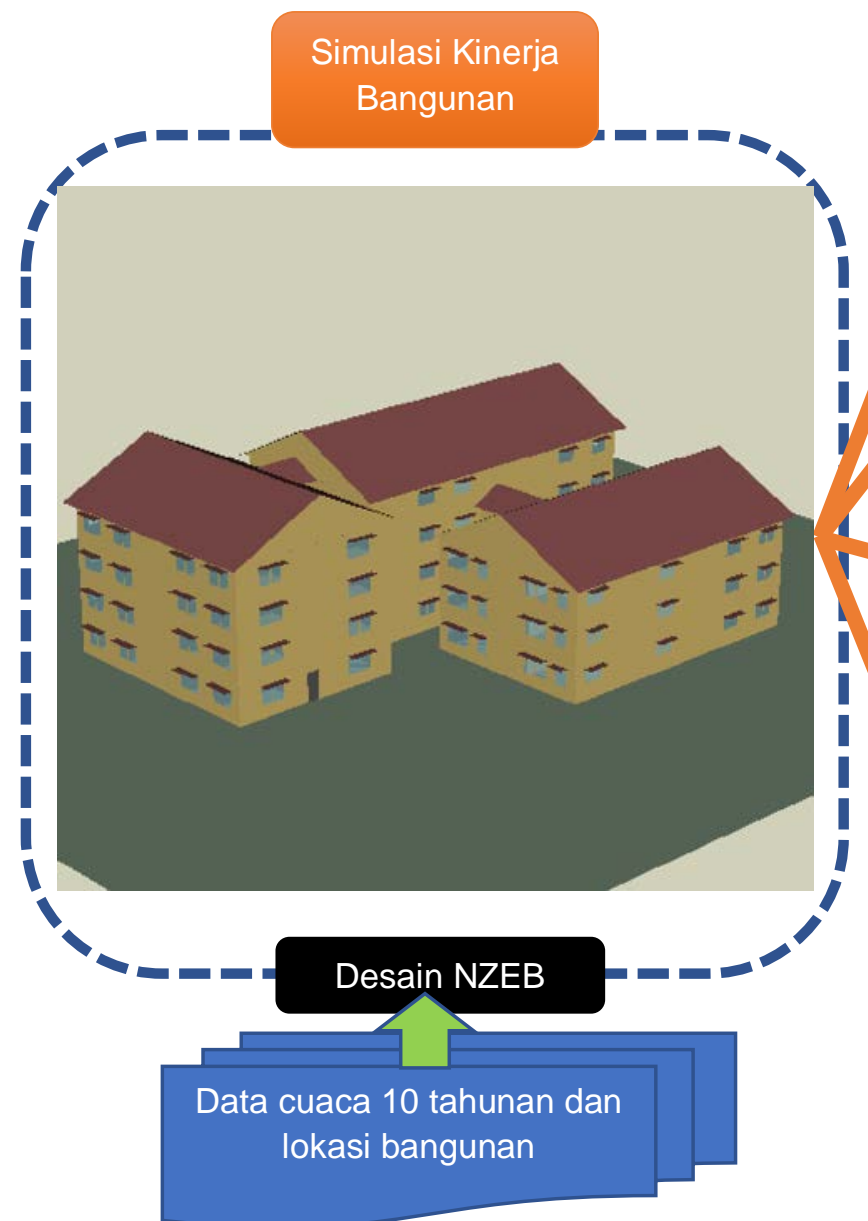

Gambar 1. Bagan alur penelitian

Penelitian bertujuan untuk menghitung seberapa besar dampak diberlakukannya Permen ESDM no. 49 tahun 2018 terhadap nilai kelayakan finansial nZEB. Untuk mencapai tujuan tersebut, penelitian ini menggunakan metode eksperimental dengan perangkat lunak simulasi kinerja energi bangunan untuk mendapatkan data konsumsi listrik tahunan sebuah bangunan. Berdasarkan hasil simulasi, semua kompinen biaya bangunan termasuk biaya listrik tahunan akan dihitung nilai pertambahan NPV biaya siklus hidup (Incremental Net Present Value) bangunan nZEB.

\section{METODE PENELITIAN}

Untuk mencapai tujuan penelitian, metode eksperimen menggunakan bantuan perangkat lunak simulasi kinerja energi bangunan. Penggunaan perangkat lunak dalam penelitian ini adalah untuk mensimulasikan kinerja konsumsi energi sebuah desain bangunan dalam kondisi cuaca dan lokasi tertentu.

Bangunan yang dijadikan sampel dalam penelitian ini adalah bangunan hunian sewa sederhana sebanyak 99 unit, terdiri dari 4 lantai, dengan luas keseluruhan bangunan $1.821 \mathrm{~m}^{2}$ termasuk area koridor dan area umum. Setiap unit rumah susun sudah dilengkapi dengan 1 kamar mandi per unit, sehingga total luas 1 unit adalah $18 \mathrm{~m}^{2}$. Spesifikasi material bangunan yang digunakan dalam penelitian ini menggunakan spesifikasi desain dan material Zero-Energy Building yang sudah dioptimalkan secara biaya dan konsumsi energi (Latief, Berawi, Koesalamwardi, Sagita, \& Herzanita, 2019; Koesalamwardi \& Rostiyanti, 2019).

Setelah memasukan data berupa spesifikasi desain dan material NZEB dan menjalankan simulasi, akan didapatkan data luaran berupa: (1) Biaya konstruksi; (2) Biaya perawatan bangunan tahunan; (3) konsumsi energi listrik tahunan; (4) Listrik yang dihasilkan dari sumber energi terbarukan, yaitu panel photovoltaic (PV). Gambar 1 di atas adalah skema alur penelitian hingga didapatkan jawaban dan tujuan penelitian.

Peningkatan desain sebuah bangunan dari konsep konvensional menuju konsep berkelanjutan seperti Green building dan nZEB akan menambah biaya konstruksi di awal karena konsep desain ini menggunakan material penghemat energi dan sistem pembangkit listrik dari sumber energi baru dan terbarukan (EBT) seperti panel PV (Gagliano, Giuffrida, Nocera, \& Detommaso, 2017). Tingginya biaya awal konstruksi menjadi salah satu kendala dalam pengembangan desain berkonsep bangunan berkelanjutan. Maka manfaat yang didapat berupa penghematan biaya operasional dan perawatan bangunan berkonsep desain ini juga patut diperhitungkan dalam sebuah analisis biaya siklus hidup (Ruparathna, Hewage, \& Sadiq, 2017). 
Penelitian menggunakan analisis pertambahan biaya siklus hidup (incremental life cycle cost analysis) yang hanya memperhitungkan pertambahan dan pengurangan seluruh komponen biaya. Angka yang akan dicari untuk menentukan kelayakan finansial adalah angka incremental Net Present Value ( $\triangle \mathrm{NPV}$ ) atau Nilai Nett Pertambahan Biaya Saat Ini. Nilai ini adalah nilai netto (kas masuk dikurangi kas keluar) dari semua arus kas yang terjadi dalam seluruh siklus hidup dikonversi ke sebuah nilai ekuivalen dengan nilai saat ini. Nilai Analisis ini digunakan untuk mempertimbangkan dua atau lebih alternatif yang bersifat saling eksklusif (mutually exclusive). Analisis ini memperhitungkan hanya perubahan atau pertambahan dalam arus kas alternatif yang sedang dianalisis. Misal, apabila alternatif baru yang sedang dianalisis menyebabkan pertambahan biaya di awal, maka pertambhan itu dapat diperhitungkan dengan sebuah nilai positif. Sedangkan apabila dalam arus kas alternatif baru ini menyebabkan adanya pengurangan atau penghematan biaya, maka dalam analisis arus kas penghematan ini diberi nilai negatif (Blank \& Tarquin, 2005). Dalam penelitian ini, pengembangan desain dari desain konvensional menjadi desain nZEB adalah alternatif yang saling eksklusif, hanya bisa memilih salah satu dari dua alternatif, menerapkan desain nZEB atau sama sekali tidak mengembangkan desain (tetap mempertahankan desain konvensional). Maka, apabila seluruh biaya tambahan netto (incremental NPV/ $\triangle \mathrm{NPV}$ ) dalam siklus hidup yang harus diinvestasikan untuk menerapkan desain nZEB ini bernilai positif (+) karena pertambahan biaya dalam arus kas lebih besar dari pada penghematan biaya yang dihasilkan, maka alternatif pengembangan ke arah desain NZEB dapat dinyatakan tidak layak secara finansial. Sebaliknya, apabila seluruh biaya tambahan netto (incremental NPV/ $\triangle N P V$ ) dalam siklus hidup yang harus diinvestasikan untuk menerapkan desain nZEB ini bernilai negatif (-) karena pertambahan biaya dalam arus kas lebih sedikit daripada penghematan biaya yang dihasilkan, maka alternatif pengembangan ke arah desain nZEB dapat dinyatakan layak secara finansial. Rumus yang digunakan untuk mendapatkan tambahan nilai nett saat ini untuk pengembangan desain adalah:

$\Delta \mathrm{NPV}=\Delta \mathrm{K}+\Delta\left[(\mathrm{P} / \mathrm{A} ; \mathrm{r} ; \mathrm{n})^{\star} \mathrm{M}\right]+\Delta\left[(\mathrm{P} / \mathrm{A} ; \mathrm{r} ; \mathrm{n})^{\star} \mathrm{L}\right]$ dimana:

$\triangle \mathrm{NPV}=$ Nilai net pertambahan biaya saat ini

$\Delta \mathrm{K}=$ Pertambahan biaya konstruksi

$\mathrm{M}=$ Biaya perawatan banguan tahunan

$L=$ Biaya tagihan listrik tahunan

$(\mathrm{P} / \mathrm{A} ; \mathrm{r} ; \mathrm{n})=$ uniform series present worth

$r=$ tingkat suku bunga dalam persen

$\mathrm{n}=$ umur periode analisis dalam tahun

Dalam memakai rumus ini, beberapa asumsi dasar digunakan, yaitu: (1) semua biaya yang dikeluarkan (cash outflow) akan diberi tanda positif, sedangkan semua pemasukan dan atau penghematan biaya (cash inflow) akan diberi tanda negatif; (2) maka apabila nilai $\triangle$ NPV bernilai negatif, maka nilai tersebut mengindikasikan adanya penghematan biaya; (3) tingkat suku bunga yang digunakan dalam perhitungan adalah
$5,625 \%$ pertahun berdasarkan nilai rata-rata tingkat suku bunga di tahun 2019; (4) periode analisis biaya siklus hidup yang digunakan (n) adalah 10 tahun; (5) harga listrik menggunakan harga tahun 2019 untuk wilayah DKI Jakarta sebesar Rp. 1.467,28/kWh; (6) Peraturan insentif terdahulu, Peraturan Direksi PLN no. 0733.K/DIR/2013 menyatakan harga beli PLN dari listrik yang dihasilkan panel PV adalah sama dengan harga beli konsumen (retail), sedangkan Peraturan Menteri ESDM no. 49 tahun 2018, menyatakan harga beli PLN untuk listrik dari konsumen pemilik panel PV adalah 65\% dari harga retail.

\section{HASIL DAN PEMBAHASAN}

Spesifikasi material penghemat energi dan panel PV menghasilkan pertambahan biaya awal konstruksi sebesar Rp. 2.079.312.000,00. Penambahan biaya berasal dari pemakaian material penghemat energi dan sistem pembangkit listrik dari sumber EBT, yaitu berupa: insulasi selulosa R-30 pada struktur atap, pemasangan drywall pada dinding bagian dalam, pemasangan kaca emsivitas rendah pada seluruh jendela, penggantian lampu CFL menjadi lampu LED untuk seluruh lampu, pemasangan kanopi $60 \mathrm{~cm}$ pada seluruh jendela, dan pemasangan panel PV pada atap bangunan berkapasitas $5.000 \mathrm{kWp}$. Adanya material tambahan ini, juga menambah biaya perawatan material tersebut. Biaya perawatan tahunan bertambah sebesar Rp. 107.211.390,79 per tahun.

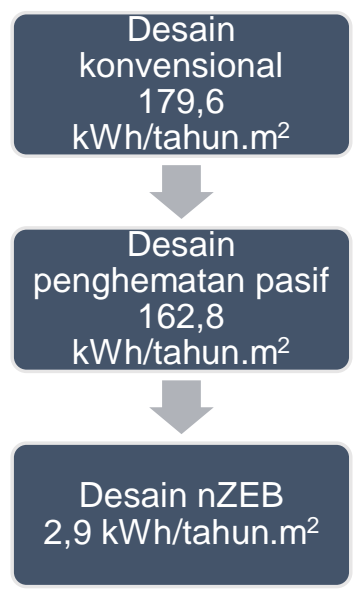

Gambar 2. Penurunan indeks energi bangunan

Walaupun biaya awal konstruksi dan perawatan tahunan bangunan bertambah, hasil simulasi kinerja energi bangunan juga mencatat adanya pengurangan (penghematan) konsumsi listrik pada bangunan per tahun. Penghematan konsumsi energi listrik setelah mengaplikasikan konsep desain nZEB mencapai 98,38\% per tahun, seperti yang digambarkan pada Gambar 2 di atas, dimana indeks konsumsi energi listrik tahunan bangunan ini berkurang dari 179,6 kWh/tahun. ${ }^{2}$ menjadi 2,9 kWh/tahun. $\mathrm{m}^{2}$. Penurunan konsumsi energi listrik tahunan dalam bangunan ini sebagian besar $(98,22 \%)$ akibat dari pemasangan panel PV. Maka dari itu 98,22\% pengurangan biaya (tagihan) listrik tahunan diperhitungkan dengan menerapkan peraturan insentif energi baru terbarukan (EBT) yang berlaku. 
Tabel 1. Biaya listrik tahunan tiap desain bangunan

\begin{tabular}{lccr}
\hline & $\begin{array}{c}\text { Konsumsi } \\
\text { listrik } \\
\text { (kWh/tahun) }\end{array}$ & $\begin{array}{c}\text { Tagihan listrik } \\
\text { tahunan } \\
\text { (Rp/tahun) }\end{array}$ & $\begin{array}{c}\text { Penghematan } \\
\text { tagihan listrik } \\
\text { (Rp/tahun) }\end{array}$ \\
\hline Desain Konvensional & 327.178 & $480.061 .735,84$ & 0 \\
\hline Desain Penghematan Pasif & 296.521 & $435.079 .332,88$ & $44.982 .402,96$ \\
\hline $\begin{array}{l}\text { Desain nZEB dengan panel PV } \\
\text { (Peraturan Direksi PLN no. 0733.K/DIR/2013) }\end{array}$ & 5.554 & $8.149 .273,12$ & $471.912 .462,72$ \\
\hline $\begin{array}{l}\text { Desain nZEB dengan panel PV } \\
\text { (Peraturan Menteri ESDM no. 49 tahun 2018) }\end{array}$ & 5.554 & $157.574 .794,04$ & $322.486 .941,80$ \\
\hline
\end{tabular}

Desain konvensional bangunan mengkonsumsi energi listrik per tahun sebesar $327.178 \mathrm{kWh} /$ tahun dengan biaya listrik tahunan sebesar Rp. 480.061.735,84 per tahun. Apabila bangunan ini menerapkan desain pasif, maka banguan ini akan mengkonsumsi energi listrik sebesar $296.521 \mathrm{kWh} /$ tahun dengan biaya listrik tahunan sebesar Rp. 435.079.332,88 per tahun. Desain pasif secara keseluruhan bangunan menghemat biaya listrik tahunan sebesar Rp. 44.982.402,96 per tahun. Desain nZEB yang mengaplikasikan sistem pembangkit listrik EBT dari panel PV, mengkonsumsi energi listrik tahunan sebesar $5.554 \mathrm{kWh} / \mathrm{tahun}$. Dengan adanya sumber EBT ini, maka pemilik bangunan dapat menjual listrik yang dihasilkan oleh panel PV ke jaringan listrik PLN dengan harga tertentu sesuai peraturan mengenai insentif EBT. Apabila menggunakan peraturan insentif terdahulu yakni Peraturan Direksi PLN no. 0733.K/DIR/2013 yang menyatakan harga beli listrik dari panel PV milik konsumen adalah sebesar harga beli retail, maka tagihan listrik untuk seluruh bangunan adalah sebesar Rp. 8.149.273,12 per tahun. Dengan peraturan insentif tahun 2013 ini, pemilik bangunan dapat menghemat biaya listrik tahunan sebesar Rp. 471.912.462,72 per tahun. Namun, apabila menggunakan peraturan insentif EBT tahun 2018 yakni Peraturan Menteri ESDM no. 49 tahun 2018 yang menyatakan harga beli listrik dari panel PV milik konsumen adalah sebesar $65 \%$ dari harga retail, maka tagihan listrik untuk seluruh bangunan adalah sebesar Rp. 157.574.794,04 per tahun. Dengan peraturan insentif EBT tahun 2018 ini, pemilik bangunan menghemat biaya listrik tahunan sebesar Rp. 322.486.941,80 per tahun. Hal ini dirangkum dan ditunjukkan pada Tabel 1 di atas.
Nilai penghematan tagihan listrik tahunan ini kemudian digunakan dalam analisis pertambahan NPV biaya $(\triangle \mathrm{NPV})$. Pertambahan NPV biaya untuk komponen bangunan, konstruksi dan perawatan adalah Rp. 1.276.016.000,00. Berdasarkan Tabel 1 sebelumnya, penerapan desain nZEB dengan panel PV akan menghasilkan penghematan biaya listrik tahunan yang bersifat mengurangi biaya. Maka dari itu, dalam analisis pertambahan nilai biaya saat ini, penghematan bernilai negatif. Penghematan biaya listrik tahunan tersebut apabila diekuivalensikan ke nilai saat ini (present), maka seluruh penghematan biaya listrik tahunan dalam 10 tahun adalah sebesar Rp. 3.535.868.631,80 di bawah peraturan insentif EBT tahun 2013 dan sebesar Rp. 1.140.261.491,63 di bawah peraturan insentif EBT tahun 2018. Penghematan biaya listrik tahunan yang ditunjukkan pada Tabel 1 sebelumnya, menjadi pertambahan negatif dalam analisis pertambahan NPV biaya. Maka sesuai dengan persamaan (1), nilai pertambahan NPV biaya dari nZEB adalah -Rp. 2.259.852.631,80 (di bawah peraturan insentif EBT tahun 2013) dan -Rp. 1.140.261.491,63 (di bawah peraturan insentif EBT tahun 2018). Nilai negatif untuk masing-masing pertambahan NPV biaya mengindikasikan dalam 10 tahun analisis biaya, desain nZEB akan menghasilkan penghematan bahkan keuntungan secara finansial. Selain itu, periode pengembalian penambahan biaya akibat penerapan konsep desain nZEB dapat dicapai selama 2,55 tahun apabila menggunakan peraturan insentif EBT tahun 2013 dan selama 5,61 tahun dengan menggunakan peraturan insentif EBT tahun 2018. Hal ini ditunjukkan pada Tabel 2.

Tabel 2. Analisis pertambahan NPV biaya nZEB di bawah peraturan insentif EBT tahun 2013 dan 2018

\begin{tabular}{|c|c|c|}
\hline & $\begin{array}{c}\text { Peraturan Direksi PLN } \\
\text { no. 0733.K/DIR/2013 }\end{array}$ & $\begin{array}{c}\text { Peraturan Menteri ESDM } \\
\text { no. } 49 \text { tahun } 2018\end{array}$ \\
\hline $\begin{array}{l}\text { Pertambahan NPV biaya material konstruksi: } \\
\text { Biaya konstruksi dan perawatan }\end{array}$ & \multicolumn{2}{|c|}{ Rp. 1.276.016.000,00 } \\
\hline $\begin{array}{l}\text { Pertambahan NPV biaya listrik tahunan: } \\
\text { Penghematan biaya listrik }\end{array}$ & -Rp. 3.535.868.631,80 & -Rp. 2.416.277.491,63 \\
\hline $\begin{array}{l}\text { Jumlah pertambahan NPV biaya seluruh } \\
\text { siklus hidup nZEB }\end{array}$ & -Rp. 2.259.852.631,80 & -Rp. 1.140.261.491,63 \\
\hline Periode pengembalian biaya tambahan & 2,55 tahun & 5,61 tahun \\
\hline
\end{tabular}




\section{KESIMPULAN}

Penerapan dan peningkatan desain bangunan untuk menjadi berkelanjutan, nyaman, dan ramah lingkungan menjadi suatu kebutuhan pada saat ini. Penerapan desain yang berkelanjutan dan ramah lingkungan seperti konsep desain nZEB membutuhkan biaya tambahan baik pada awal konstruksi hingga pada saat fase operasional bangunan untuk perawatannya. Model bangunan penelitian ini mengalami penambahan biaya awal konstruksi sebesar Rp. 2.079.312.000,00 dan biaya perawatan tahunan sebesar Rp. 107.211.390,79 per tahun untuk menerapkan material, alat dan sistem penghemat energi serta panel photovoltaic untuk menghasilkan listrik dari sinar matahari.

Penerapan konsep desain nZEB berhasil menurunkan indeks konsumsi energi listrik sejauh 98,38\%, dari 179,6 $\mathrm{kWh} /$ tahun. $\mathrm{m}^{2}$ menjadi 2,9 kWh/tahun. $\mathrm{m}^{2}$. Sebagian besar pengurangan konsumsi listrik dari bangunan tersebut berasal dari energi listrik yang dihasilkan oleh panel photovoltaic yang dipasang di atap bangunan. Pengurangan konsumsi listrik pada bangunan ini tentu akan diikuti dengan penghematan biaya listrik tahunan bangunan. Besaran dari penghematan biaya listrik tahunan bangunan nZEB sangat bergantung dari peraturan insentif EBT yang digunakan. Peraturan Direksi PLN no. 0733.K/DIR/2013 tahun 2013 menyatakan harga beli PLN dari listrik yang dihasilkan panel PV adalah sama dengan harga beli konsumen (retail), sedangkan Peraturan Menteri ESDM no. 49 tahun 2018, menyatakan harga beli PLN untuk listrik dari konsumen pemilik panel PV adalah $65 \%$ dari harga retail. Penghematan biaya istrik tahunan model nZEB dengan menggunakan peraturan insentif EBT tahun 2013 mencapai Rp. 471.912.462,72 per tahun, sedangkan dengan peraturan insentif EBT tahun 2018 ini, pemilik bangunan menghemat biaya listrik tahunan sebesar Rp. 322.486.941,80 per tahun.

Akumulasi penghematan biaya listrik tahunan tersebut selama 10 tahun masa analisis pertambahan NPV biaya nZEB menyimpulkan bahwa kedua peraturan insentif EBT dapat menghasilkan nilai pertambahan NPV biaya negatif yang mengindikasikan desain nZEB akan menghasilkan penghematan bahkan keuntungan secara finansial. Akan tetapi, besarnya nilai kelayakan finansial untuk tiap peraturan insentif berbeda. Nilai pertambahan NPV biaya siklus hidup nZEB di bawah peraturan insentif EBT tahun 2013 memiliki nilai NPV negatif yang lebih besar yakni -Rp. 2.259.852.631,80 . Selain itu, peraturan insentif EBT 2013 dapat mengembalikan modal pertambahan biaya untuk penerapan konsep desain nZEB kepada pemilik bangunan dalam periode 2,55 tahun; 2 kali lebih cepat apabila menggunakan peraturan insentif tahun 2018. Kedua indikator analisis kelayakan finasial ini menyimpulkan keuntungan finansial yang dihasilkan peraturan insentif EBT tahun 2013 lebih besar daripada peraturan insentif EBT tahun 2018.

\section{REFERENSI}

Abdellah, R. H., Masrom, A. N., Chen, G. K., Mohammed, S., \& Omar, R. (2017). The potential of net zero energy buildings (NZEBs) concept at design stage for healthcare buildings towards sustainable development . Global Congress on Construction, Material and Structural Engineering 2017 (GCoMSE2017). Johor Bahru: IOP Publishing Ltd.

Bank Indonesia. (2018, May 14). Perkembangan Properti Komersial. Diambil kembali dari Bank Sentral Republik Indonesia:

https://www.bi.go.id/id/publikasi/survei/properti -komersial/Default.aspx

Berawi, M. A., Basten, V., Latief, Y., \& Crévits, I. (2020). Green building incentive model during design recognition to ensure the reliability of green building operation and maintenance achievement. International Conference on Eco Engineering Development. Solo: IOP Conference Series: Earth and Environmental Science. doi:https://doi.org/10.1088/17551315/426/1/012020

Blank, L., \& Tarquin, A. (2005). Engineering Economy (6th ed.). New York: McGraw-Hill.

Dávi, G. A., Caamaño-Martín, E., Rüther, R., \& Solano, J. (2016). Energy performance evaluation of a net plus-energy residential building with grid-connected photovoltaic system in Brazil. Energy and Buildings, 19-29.

Gagliano, A., Giuffrida, S., Nocera, F., \& Detommaso, M. (2017). Energy efficient measure to upgrade a multistory residential in a nZEB. AIMS Energy, 601-624.

\section{International Energy Agency and} United Nations Environment Programme. (2017). 2017 Global Status Report: Towards a zero-emission, efficient and resilient buildings and construction sector.

United Nations Environment Programme.

Koesalamwardi, A. B., \& Rostiyanti, S. F. (2019). Cost Optimum Design of Zero-Energy Residential Building. International Seminar on Tropical Eco-Settlements (hal. 96-112). Denpasar, Bali: Knowledge-E.

Latief, Y., Berawi, M. A., Koesalamwardi, A. B., Riantini, L. S., \& Petroceany, J. S. (2017, December 27). Defining Design Parameters for Housing Development in Tropical Climates Using The Near Zero Energy House (nZEH) Concept. International Journal of Technology, 8(6), 1134-1140. doi:https://doi.org/10.14716/ijtech.v8i6.719 
Latief, Y., Berawi, M. A., Koesalamwardi, A. B., Sagita, L., \& Herzanita, A. (2019, Februari). Cost Optimum Design of Tropical Near Zero Energy House. International Journal of Technology, 10(2), 376-385.

Latief, Y., Berawi, M. A., Supriadi, L., Koesalamwardi, A. B., Petroceany, J., \& Herzanita, A. (2017). Integration of net zero energy building with smart grid to improve regional electrification ratio towards sustainable development. The International Conference on Eco Engineering Development 2017. 109. Yogyakarta: IOP Conference Series: Earth and Environmental Science. doi:https://doi.org/10.1088/17551315/109/1/012041
Ruparathna, R., Hewage, K., \& Sadiq, R. (2017). Economic evaluation of building energy retrofits: A fuzzy based approach. Energy and Buildings, 395-406.

Sarkar, D., Kumar, A., \& Sadhu, P. K. (2019). A Survey on Development and Recent Trends of Renewable Energy Generation from BIPV Systems. IETE Technical Review. doi:10.1080/02564602.2019.1598294

World Bank. (2016, June 14). Feature Story: Indonesia's Urban Story. Dipetik June 08, 2018, dari

http://www.worldbank.org/en/news/feature/201 6/06/14/indonesia-urban-story 